Article

\title{
Intensification of Organophosphorus Hydrolase Synthesis by Using Substances with Gas-Transport Function
}

\author{
Olga Senko ${ }^{1}$, Nikolay Stepanov ${ }^{1}$, Andrey Tyutyunov ${ }^{2}$, Sergey Sterlin ${ }^{2}$, Vitaly Grinberg ${ }^{3}$, \\ Tatiana Makhlis ${ }^{1}$ and Elena Efremenko ${ }^{1, *}$ \\ 1 Faculty of Chemistry, Lomonosov Moscow State University, Moscow 119991, Russia; \\ senkoov@gmail.com (O.S.); na.stepanov@gmail.com (N.S.); tmakhlis@mail.ru (T.M.) \\ 2 A. N. Nesmeyanov Institute of Organoelement Compounds of Russian Academy of Sciences, \\ Moscow 119991, Russia; tuytuynov@rambler.ru (A.T.); sterlins@yandex.ru (S.S.) \\ 3 A. N. Frumkin Institute of Physical Chemistry and Electrochemistry of Russian Academy of Sciences, \\ Moscow 119071, Russia; vgrinberg@phyche.ac.ru \\ * Correspondence: elena_efremenko@list.ru; Tel.: +7-495-939-3170
}

Received: 3 November 2017; Accepted: 13 December 2017; Published: 17 December 2017

\begin{abstract}
We have performed studies and comparative analysis of the biosynthesis characteristics of intracellular recombinant enzyme, such as hexahistidine-containing organophosphorus hydrolase $\left(\mathrm{His}_{6}-\mathrm{OPH}\right)$ in Escherichia coli SG13009[pREP4] cells when various perfluorocarbon compounds (PFC) were introduced into the medium for cell cultivation. The PFC were found to facilitate the biosynthesis of $\mathrm{His}_{6}-\mathrm{OPH}$ : increased levels of the total OPH-activity (up to $37 \%$ ) were measured upon introduction of 1,1,1,2,2,3,3,4,4,5,5,6,6,6-tetradecafluorohexane (PFH) and 4,7,10,13,16,19,22,25,28,31-decaoxaperfluoro-5,8,11,14,17,18,21,24,27,30-decamethyl tetratriacontane (Polyether II) into culture medium. We have demonstrated the possibility of effective and multiple (at least five-fold) use of $\mathrm{PFH}$ for biosynthesis of intracellular recombinant protein $\mathrm{His}_{6}-\mathrm{OPH}$, which catalyzes the hydrolysis of organophosphorus pesticides (OP), is widely used in agriculture and can be applied as new antidote for OP-detoxification in vivo. The multiple use of PFH was achieved through recycling of this substance: sediment of Escherichia coli SG13009[pREP4] cell biomass was collected at the end of each culture growing step and disintegrated with ultrasound, and obtained residue containing almost all of the initially introduced PFC was then added to the medium at the start of the following culture growing step.
\end{abstract}

Keywords: perfluorocarbon compounds; perfluorohexane; recombinant intracellular protein; hexahisdine-containing organophosphorus hydrolase; Escherichia coli

\section{Introduction}

Many modern biotechnological processes use recombinant cells as producers of different target products, and bacteria Escherichia coli are microorganisms that are most widely used for producing genetically modified proteins [1,2]. This is due to the wealth of knowledge on this species, high cell growth rate, the accessibility of modern techniques for genetic manipulation, and great progress in realization of biotechnological processes. In particular, E. coli cells are used for producing therapeutic proteins and industrial enzymes (restriction enzymes, DNA polymerase, enterokinase, L-asparaginase, streptokinase, ligases, amylases, invertase, cellulases, xylanase, etc.), antibodies, growth factors, interferons, insulin) [3-7].

In order to optimize such processes, the biotechnologists usually aim at maximizing such process characteristics as the growth rate of the bacterial cells, the rate of biomass increase, and that of target 
substance accumulation in the bacterial cells. This approach allows for reducing the costs, first of all in terms of energy consumption. The efficiency of the biotechnological processes involving high concentrations of aerobic producing cells is often limited by the intensity of mass exchanged processes, in particular, that of mass transfer of air in the medium [8]. In most cases, the mass exchange is enhanced via increasing the rate of air flow into the reactor, or the intensity of mechanical or bubble mixing. However, this increases the turbulence of the liquid flow in the reactor and causes negative respond of cultivated cells as result of their shear deformation or stress [9].

Application of perfluorocarbon compounds (PFCs) as oxygen carriers is considered as one of the prospective approaches to increasing the efficiency of the biotechnological processes with different types of microorganisms. PFCs are derivatives of aliphatic, cyclic, or polycyclic hydrocarbons, where most of the hydrogen atoms (or even all of them) are substituted with fluorine [10]. The basic feature of PFCs, which ensures their efficient use in biotechnology, is the solubility of oxygen in such substances (up to 20 times that in water). Besides, PFCs are highly neutral (both chemically and biologically), stable, and have low toxicity towards biological systems. Most of such substances, depending on their boiling temperature, can be sterilized via autoclaving [11]. Being hydrophobic, most PFCs can be easily separated from the water phase, and can be re-used (upon regeneration, when necessary) in the biotechnological processes [12].

It is known that the introduction of perfluorodecalin (PFD) into the media for cultivation of microorganisms allows for increasing the amount of accumulated biomass and to reduce the required cultivation time [13]. Many researchers have shown that the use of PFD as an additive in cultivation of recombinant bacterial strains can help increasing both the biomass output and, in certain cases, the level of recombinant protein expression [14,15]. However, PFD is currently almost the only substance among the many known PFCs, which is actively used in such studies [16]. Note that to achieve the necessary results, rather large quantities of PFD have to be introduced into the medium (5-50 vol. \%) [14]. Thus, the introduction of PFD at 50 vol. \% produces a $40 \%$ increase in the biomass output of genetically modified E.coli RB791 pAdh cells, which synthesizes the recombinant alcohol dehydrogenase [17]. In another case, a $20 \%$ increase in amount of accumulated biomass for genetically modified E. coli RB791 pQE30adh cells was observed when 50 vol. \% of PFD was added to the culture medium $[15,18]$. Note that lower concentrations of PFD in some cases proved more effective. In particular, addition of $0.5-12.5 \mathrm{vol}$. \% of PFD to the medium caused an increase in cell suspension density by a factor of up to 3, and the transition from the exponential to the stationary phase of growth for the E. coli M-17 strain was observed $1 \mathrm{~h}$ earlier than in the control sample without PFD [13]. Thus, the application of relatively low concentrations of PFD appears to be more attractive for enhancing the parameters of biotechnological processes involving recombinant cells. Despite the positive results that are achieved, addition of PFD to the culture growth media has not been used so far on the industrial scale, because the relatively high concentrations that are required, as well as the high cost of this substance makes this approach economically unviable for large-scale biotechnological processes. One of the ways to address this issue is multiple re-use of PFD in the biotechnological process, so that several production cycles can benefit from the use of the same portion of PFD, thus multiplying the target product output at lower cost.

The possibility of separation of PFD from the culture medium upon completion of the processes via precipitation of this compound to the bottom of the reactor in case of periodical cultivation was previously shown [12]. However, this way of PFD separation works only for the processes where the target product of fermentation is an extracellular compound (e.g., antibiotic, hormone, secreted protein, etc.). In the cases when obtaining the intracellular target product (e.g., enzyme) involves biomass accumulation, followed by cell disintegration, the separation of cell precipitate from the layer of PFD actually is impossible by the regular way, and special procedures should be developed.

Concurrently, an alternative approach to solving the problems of PFD application consists in looking for other PFCs with gas transfer function, which could affect the biotechnological processes in the same way as PFD does, but at much lower concentration of PFCs that are introduced into the cell 
culture medium. Carbogal and perfluoromethyldecalin are discussed as prospective substances for such studies [19], and perfluorohexane (PFH) also is noted [20]. However, only a few studies of the use of these compounds in processes involving recombinant $E$. coli cells have been performed so far.

Hexahistidine-containing organophosphorus hydrolase $\left(\mathrm{His}_{6}-\mathrm{OPH}\right)$ is one of the valuable intracellular enzymes produced using recombinant $E$. coli cells (sequence of parent enzyme is available at UniProtKB P0A434). This enzyme can be applied for decomposing highly toxic organophosphorous substances previously produced as chemical weapon agents. Detoxification of such substances and of the products of their decomposition is essential for realizing the international programs on chemical disarmament [21]. Another important application for this enzyme is producing the unique and most modern antidotes that can be used against neurotoxic pesticides and chemical toxins [22]. Yet another application for this enzyme is developing new chemical agents with lactonase activity, which, being used in combination with antibiotics, can enhance the efficiency of the latter against antibiotic-resistant populations of gram-negative bacteria $[23,24]$. Thus, biotechnological studies that are aimed at enhancing the efficiency of $\mathrm{His}_{6}-\mathrm{OPH}$ synthesis are very topical.

The purpose of this paper was studying the influence of various PFCs on the efficiency of biotechnological processes, as well as investigating the possibility of multiple reuse of PFCs in the process of recombinant E. coli SG13009[pREP4] cell cultivation in order to produce the intracellular $\mathrm{His}_{6}-\mathrm{OPH}$.

\section{Materials and Methods}

\subsection{Biological and Chemical Materials}

Recombinant E. coli strain SG13009[pREP4] (Qiagen, Hilden, Germany), transformed with pTES$\mathrm{His}_{6}-\mathrm{OPH}$ plasmid encoding $\mathrm{His}_{6}-\mathrm{OPH}$ synthesis was used for enzyme production. Gene encoding OPH synthesis was obtained from Pseudomonas diminuta VKM B-1279 cells [25].

As a basis, the known crystallographic structure of OPH dimer (PDB number 1QW7) was used with preliminary modification by His6-tag as described in work of Lyagin; I.V., Efremenko E.N. (2017) [26].

We used the following PFCs: perfluorohexane (HaloPolymer, Moscow, Russia), perfluorodecalin (Acros Organics, Geel, Belgium), as well as new compounds of the perfluoroether class with molecular formula $\left[\mathrm{C}_{3} \mathrm{~F}_{3} \mathrm{O}\left(\mathrm{C}_{2} \mathrm{~F}_{4} \mathrm{CF}_{2} \mathrm{O}\right)_{3} \mathrm{C}_{2} \mathrm{~F}_{4}\right]_{2}$ (polyether I) and 3,6-dioxaperfluoro-5-methylnonane $\mathrm{C}_{3} \mathrm{~F}_{7} \mathrm{OCF}\left(\mathrm{CF}_{3}\right) \mathrm{CF}_{2} \mathrm{OC}_{2} \mathrm{~F}_{5}$ (polyether II). The latter two compounds have higher molecular mass and higher gas transfer capacity when compared to PFD (Table 1). The concentration of PFC additives in the growth medium was $0.1,1,3$, and $5 \%(v / v)$.

Table 1. Physico-chemical properties of perfluorocarbon compounds (PFCs) used in this study.

\begin{tabular}{|c|c|c|c|}
\hline PFCs & $\begin{array}{c}\text { Molecular } \\
\text { Mass (g/mol) }\end{array}$ & $\begin{array}{l}\mathrm{O}_{2} \text { Solubility } \\
\text { at } 298 \mathrm{~K} \\
(\% v / v)\end{array}$ & $\begin{array}{l}\text { Density } \\
\left(\mathrm{kg} / \mathrm{m}^{3}\right)\end{array}$ \\
\hline $\begin{array}{c}\text { 1,1,1,2,2,3,3,4,4,5,5,6,6,6-tetradecafluorohexane } \\
\text { Perfluorohexane } \\
\mathrm{CF}_{3}\left(\mathrm{CF}_{2}\right)_{4} \mathrm{CF}_{3}\end{array}$ & 337.90 * & 55.5 & $1.678^{*}$ \\
\hline $\begin{array}{l}\text { 3,6-dioxaperfluoro-5-methylnonane } \\
\text { (Polyether I) } \mathrm{C}_{3} \mathrm{~F}_{7} \mathrm{OCF}\left(\mathrm{CF}_{3}\right) \mathrm{CF}_{2} \mathrm{OC}_{2} \mathrm{~F}_{5}\end{array}$ & 470.05 & 52.0 & 1.790 \\
\hline 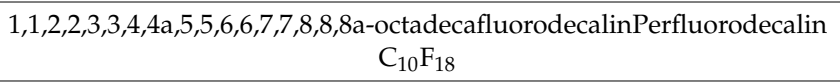 & $461.98 *$ & 45.0 & $1.930 *$ \\
\hline $\begin{array}{c}\text { 4,7,10,13,16,19,22,25-octaoxaperfluoro- } \\
\text { 5,8,11,14,17,18,21,24-octamethyloctacosane } \\
\text { (Polyether II) }\left[\mathrm{C}_{3} \mathrm{~F}_{3} \mathrm{O}\left(\mathrm{C}_{2} \mathrm{~F}_{4} \mathrm{CF}_{2} \mathrm{O}\right)_{4} \mathrm{C}_{2} \mathrm{~F}_{4}\right]_{2}\end{array}$ & 1746.26 & 53.0 & 1.804 \\
\hline
\end{tabular}




\subsection{Synthesis of Perfluoroethers}

Synthesis of 3,6-dioxaperfluoro-5-methylnonane (polyether I). The trimer of hexafluoropropene oxide (III) was stirred with $\mathrm{SbF}_{5}(1 \%-1.5 \%(w / w))$ for $\sim 1 \mathrm{~h}$ in order to remove the traces of diglyme. After that acyl fluoride III was decanted from resinous precipitate. The mixture of $20 \mathrm{~g}(40 \mathrm{mmol})$ III and $3 \mathrm{~g} \mathrm{SbF}_{5}$ was stirred for several hours while the reaction mixture was gradually heated up to $70-75^{\circ} \mathrm{C}$, and gas evolution (CO) was observed. After the decarbonylation was over (the reaction was controlled by NMR- ${ }^{19} \mathrm{~F}$ ), the reaction mixture was poured into crushed ice, washed sequentially with $10 \%$ aq. $\mathrm{HCl}$, water and $30 \%$ aq. $\mathrm{K}_{2} \mathrm{CO}_{3}$, dried over $\mathrm{MgSO}_{4}$ and distilled to give $15 \mathrm{~g}(80 \%)$ III, b.p. 93-94 ${ }^{\circ} \mathrm{C}$ (lit.: $93-94{ }^{\circ} \mathrm{C}$ ).

Synthesis of polyether II. The mixture of $20 \mathrm{~g}(20 \mathrm{mmol})$ hexamer of hexafluoropropene oxide (IV), $3.5 \mathrm{~mL} \mathrm{H}_{2} \mathrm{O}$ and $15 \mathrm{~mL}$ hexane was stirred vigorously for $1 \mathrm{~h}$ until exothermic reaction ceased, lower layer was separated, acidified with $3 \mathrm{~mL}$ of conc. $\mathrm{H}_{2} \mathrm{SO}_{4}$, distilled under reduced pressure and then redistilled to give $17.5 \mathrm{~g}(88 \%)$ 4,7,10,13,16-pentaoxaperfluoro-5,8,11,14,17-pentamethyloctadecanoic acid (V), b.p. $147-148^{\circ} \mathrm{C} / 1$ Torr.

A mixture of acid V (14 g, $14 \mathrm{mmol}), \mathrm{KOH}(0.122 \mathrm{~g}, 2.2 \mathrm{mmol}), 29 \mathrm{ml} \mathrm{MeCN}$, and $1 \mathrm{~mL} \mathrm{H}_{2} \mathrm{O}$ was electrolyzed at a $\mathrm{Pt} / 10 \%$ Ir anode $\left(15 \mathrm{~cm}^{2}\right)$ using a stainless steel cathode $\left(2 \mathrm{~cm}^{2}\right)$ in a one-compartment cell at $30-35{ }^{\circ} \mathrm{C}$ (current $0.8 \mathrm{~A}$, current density $51.6 \mathrm{~mA} \mathrm{~cm}^{-2}$, initial electrolyzer voltage $24 \mathrm{~V}$, theoretical charge for consumption of $11.8 \mathrm{mmol}$ of acid $0.32 \mathrm{~A}-\mathrm{h}$ ). After passing $0.37 \mathrm{~A}-\mathrm{h}$, the final voltage was $40 \mathrm{~V}$. Then, the electrolyte was washed with water and aq. $\mathrm{K}_{2} \mathrm{CO}_{3}$ solution, the organic layer was separated and distilled to give $9.2 \mathrm{~g}$ (yield $82 \%$ by substance and $71 \%$ by current) of 4,7,10,13,16,19,22,25-octaoxaperfluoro-5,8,11,14,17,18,21,24-octamethyloctacosane II (diastereomers mixture), b.p. $161-164{ }^{\circ} \mathrm{C} / 1$ Torr.

Found \%: C 21.70; F 69.53. $\mathrm{C}_{28} \mathrm{~F}_{58} \mathrm{O}_{8}$. Calc. \%: C 21.46; F 70.37. The spectrum ${ }^{19} \mathrm{~F}-\mathrm{NMR}$ of II (the spectrum was recorded using a Bruker AVANCE-300 spectrometer at $282 \mathrm{MHz}$.

Chemical shifts are given in ppm vs. $\mathrm{CFCl}_{3}$. Downfield shifts are positive):

$\left[\mathrm{CF}_{3} \mathrm{CF}_{2} \mathrm{CF}_{2} \mathrm{OCF}\left(\mathrm{CF}_{3}\right) \mathrm{CF}_{2} \mathrm{OCF}\left(\mathrm{CF}_{3}\right) \mathrm{CF}_{2} \mathrm{OCF}\left(\mathrm{CF}_{3}\right) \mathrm{CF}_{2} \mathrm{OCF}\left(\mathrm{CF}_{3}\right)\right]_{2}$

$\mathrm{CF}_{3} \mathrm{CF}_{2} \mathrm{CF}_{2}, 84.69(6 \mathrm{~F}, \mathrm{~s}) ; \mathrm{CF}_{3} \mathrm{CF}_{2} \mathrm{CF}_{2}, 132.63(4 \mathrm{~F}, \mathrm{~s})$;

$\left[\mathrm{CF}_{3} \mathrm{CF}_{2} \mathrm{CF}_{2} \mathrm{OCF}\left(\mathrm{CF}_{3}\right) \mathrm{CF}_{2} \mathrm{OCF}\left(\mathrm{CF}_{3}\right) \mathrm{CF}_{2} \mathrm{OCF}\left(\mathrm{CF}_{3}\right) \mathrm{CF}_{2} \mathrm{OCF}\left(\mathrm{CF}_{3}\right)\right]_{2}$, 80-85.1 (a group of signals (40 F); $\mathrm{CF}\left(\mathrm{CF}_{3}\right) \mathrm{CF}\left(\mathrm{CF}_{3}\right), 143.26$ (2F, br.m); $\mathrm{OCF}\left(\mathrm{CF}_{3}\right) \mathrm{CF}_{2} \mathrm{O}, 147.26$ (6F, br.m).

The acyl fluorides III-IV were supplied by "P\&M-Invest" Ltd., Moscow, Russia.

\subsection{General Experimental Procedures}

Cells were cultivated with or without PFCs under the following conditions: inoculum of $E$. coli SG13009[pREP4] cells was grown at $30{ }^{\circ} \mathrm{C}$ in Luria-Bertani (LB) medium containing $100 \mu \mathrm{g} \mathrm{mL}^{-1}$ ampicillin and $25 \mu \mathrm{g} \mathrm{mL}^{-1}$ kanamycin. An overnight culture was inoculated to the TYE (Tryptone Yeast extrac) medium [28].

Cells of E. coli strain SG13009[pREP4] were cultivated in case of the 1st cycle of biomass accumulation in the TYE growth medium, with the following composition $(\mathrm{g} / \mathrm{L})$ : yeast extract-24, tryptone-12, glycerine-4, $\mathrm{KH}_{2} \mathrm{PO}_{4}-6.95, \mathrm{~K}_{2} \mathrm{HPO}_{4}{ }^{*} 3 \mathrm{H}_{2} \mathrm{O}-12.54$. $\mathrm{pH}$ of the medium was 7.0. When the cell debris that was obtained after the previous cycle of biomass accumulation was introduced into the culture medium, the concentration of the yeast extract additive was reduced to $18 \mathrm{~g} / \mathrm{L}$ in the medium for next round of cultivation.

IPTG (Isopropyl $\beta$-D-1-thiogalactopyranoside) was added to the medium to a final concentration of $0.2 \mathrm{mM}$ when $\mathrm{OD}_{540}$ was 0.6 . Cell cultivation was continued for $24 \mathrm{~h}$ in a thermostatically controlled shaker LT-X Lab-Therm (Adolf Kühner AG, Basel, Switzerland) with constant agitation $\left(32{ }^{\circ} \mathrm{C}\right.$, $200 \mathrm{rpm})$.

Cell growth was traced using spectrophotometry via the monitoring the optical absorbance of the culture liquid samples at $540 \mathrm{~nm}$ with Agilent UV-853 spectrophotometer (Agilent Technology, Waldbronn, Germany). The exact cell concentration was evaluated using calibration curves showing optical absorbance level vs. exact cell concentration in the analyzed sample. 
Upon the completion of cultivation, the bacterial biomass was separated from the culture liquid via centrifuging at $8000 \mathrm{~g}$ for $10 \mathrm{~min}$ (Avanti J 25, Beckman Coulter, Brea, CA, USA). Cell biomass was suspended in $0.05 \mathrm{M} \mathrm{K}$-phosphate buffer ( $\mathrm{pH}$ 7.5), containing $0.3 \mathrm{M} \mathrm{NaCl}$ in ratio 1:5 and then homogenized by sonication on ice [28]. Cell debris containing PFH was removed by centrifugation for $20 \mathrm{~min}$ at $12,000 \mathrm{~g}$ and used again in the experiments.

\subsection{Analysis Methods}

Catalytic activity of $\mathrm{His}_{6}-\mathrm{OPH}$ was evaluated, as described earlier [28]. The rates of enzymatic hydrolysis of Paraoxon used as substrate was determined with UV-visible spectroscopy by the formation of p-nitrophenol ( $405 \mathrm{~nm}, \varepsilon 405=18,000 \mathrm{M}^{-1} \mathrm{~cm}^{-1}$ ) at $25^{\circ} \mathrm{C}$ in $50 \mathrm{mM}$ carbonate buffer ( $\mathrm{pH}$ 10.5). One unit of enzymatic activity (EU) was defined as the enzyme amount that hydrolyzed $1 \mu \mathrm{mol}$ of Paraoxon per min. The total $\mathrm{His}_{6}-\mathrm{OPH}$ activity was determined as number of activity units produced in $1 \mathrm{~L}$ of culture liquid.

Cells dry weight (CDW) was determined by allowing a sample of cell biomass separated from the culture fluid by centrifugation (10,000 rpm, $5 \mathrm{~min}$ ) on an Avanti J25 centrifuge (Beckman Coulter, Brea, CA, USA) to dry to constant weight. Specific growth rate constant $(\mu)$ was calculated as describe Berney, M. et al. (2006) [29].

The concentration of protein was determined by the Bradford method (Bio-Rad, Hercules, CA, USA). Proteins were analyzed by SDS-PAGE (Sodium dodecyl sulfate-polyacrylamide gel electrophoresis) in a 12\% polyacrylamide gel (PAAG) in a Miniprotean II cell (BioRad), followed by Coomassie Blue (R-250) staining. The oligomerization grade of purified $\mathrm{His}_{6}-\mathrm{OPH}$ was estimated by PAGE under non-denaturing conditions in a 7.5\% polyacrylamide gel. Relative quantities of proteins and polypeptides were estimated using the SigmaGel Program (Jandel Corp., San Rafael, CA, USA).

\section{Results}

\subsection{Cultivation of Recombinant Protein-Producing Cells in Media Containing PFCs}

Perfluorohexane (PFH), perfluorodecalin (PFD), and perfluoroaliphatic ethers I and II, with different characteristics as gas-transfer substances, were used in this study (Table 1). Their choice was based on the physico-chemical properties of these compounds, which differ essentially from those of other substances of the same type. The physical properties of these compounds determine the conditions of their application in biotechnological processes and the possible ways of their recycling for multiple use, and also, most probably, the degree of their influence on the parameters of the biotechnological process. PFH had the lowest boiling temperature and molecular mass, and had the highest solubility in water $[11,13,17,30,31]$.

Analysis of the influence of these substances on the growth of E. coli SG13009[pREP4] cells that were transformed with pTES-His ${ }_{6}-\mathrm{OPH}$ plasmid and on the synthesis of the $\mathrm{His}_{6}-\mathrm{OPH}$ was performed via varying the initial concentrations of these PFCs in the initial culture medium in the range of $0.3 \%-5 \%(v / v)$ (Figure 1a,b, Table 2). Cultivating of the same cell strain under identical conditions, but in the absence of PFCs was used for control.

The obtained results showed that the introduction of any of the studied gas transfer-capable substances with concentration up to $3 \%(v / v)$ leads to an increase of the biomass of the cells (Figure 1a) producing $\mathrm{His}_{6}-\mathrm{OPH}$, and also, in some cases, to an increase of the $\mathrm{His}_{6}-\mathrm{OPH}$ activity of the cells per $1 \mathrm{~g}$ of dry biomass (Figure $1 \mathrm{~b}$ ).

The studies have shown that introduction of PFD into the medium for cultivating E. coli SG13009[pREP4] cells transformed with pTES-His $_{6}$-OPH plasmid leads to a very slight increase in the accumulated biomass (by $\sim 1 \%-2 \%$ ) of the total output, and the specific $\mathrm{His}_{6}$-OPH activity was $3 \%$ greater (Figure $1 \mathrm{a}, \mathrm{b}$ ).

Addition of $0.5 \%(v / v)$ of $\mathrm{PFH}$ to the culture liquid caused the maximum $\mathrm{His}_{6}$-OPH-activity of the cells when compared to the cases of all the other PFCs (and their concentrations) studied, whereas the 
level of biomass accumulation in the medium was close to the average one (Figure 1a). It was also established that increasing the concentration of this substance beyond $1 \%(v / v)$ caused a decrease of the specific $\mathrm{His}_{6}-\mathrm{OPH}$-activity of the cells (Figure 1b).

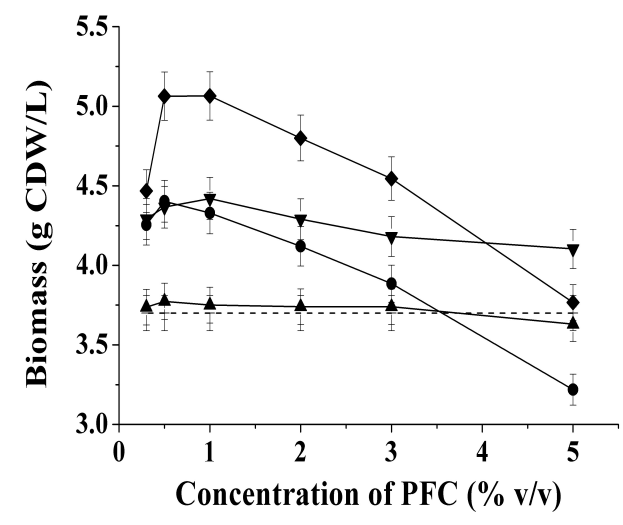

(a)

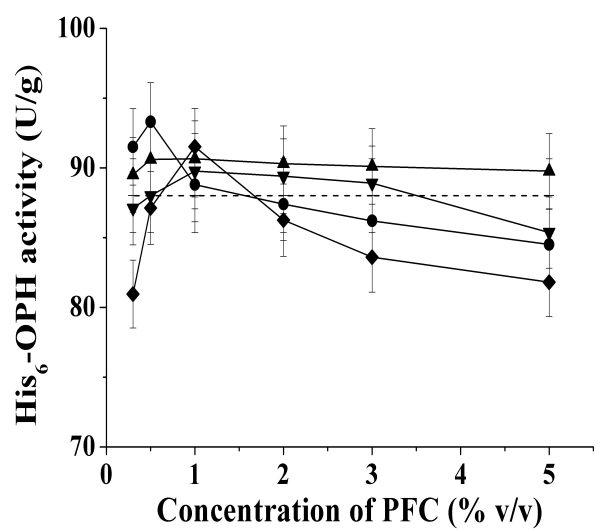

(b)

Figure 1. The accumulated biomass of E. coli SG13009[pREP4] cells (a) and His ${ }_{6}-\mathrm{OPH}$-activity in the cells (b) vs. initial concentration of the additive ( $-\mathrm{PFH}, \mathbf{\Delta}-$ polyether I, $\mathbf{\Delta}-\mathrm{PFD}, \downarrow-$ polyether II) Control sample (without PFC additives) is marked by dashed line.

Table 2. Specific cell growth rate $\left(\mu, \mathrm{h}^{-1}\right)$ for E. coli SG13009[pREP4] for various concentrations of PFCs in the culture medium *.

\begin{tabular}{cccccc}
\hline PFC $(\%$ v/v) & $\mathbf{0 . 3}$ & $\mathbf{0 . 5}$ & $\mathbf{1}$ & $\mathbf{3}$ & $\mathbf{5}$ \\
\hline PFH & $0.363 \pm 0.015$ & $0.368 \pm 0.017$ & $0.374 \pm 0.017$ & $0.351 \pm 0.014$ & $0.349 \pm 0.013$ \\
PFD & $0.345 \pm 0.012$ & $0.345 \pm 0.012$ & $0.345 \pm 0.012$ & $0.346 \pm 0.012$ & $0.345 \pm 0.012$ \\
Polyether I & $0.352 \pm 0.014$ & $0.357 \pm 0.015$ & $0.358 \pm 0.014$ & $0.353 \pm 0.014$ & $0.347 \pm 0.012$ \\
Polyether II & $0.367 \pm 0.016$ & $0.369 \pm 0.016$ & $0.376 \pm 0.017$ & $0.352 \pm 0.014$ & $0.349 \pm 0.013$ \\
\hline \multicolumn{5}{c}{ * Specific cell growth rate in the absence of PFCs was $0.344 \pm 0.011 \mathrm{~h}^{-1}}$.
\end{tabular}

The specific cell growth rate for E. coli SG13009[pREP4] upon the addition of gas transfer-capable substances to the culture medium was almost the same as in the absence of such substances (Table 2). However, after $24 \mathrm{~h}$ of cultivating cells in the absence of PFCs, the stationary growth phase was reached, whereas in the presence of PFCs, the growth after $24 \mathrm{~h}$ still demonstrated logarithmic manner, so that the total biomass output that is presented in Figure 1a was greater in the latter case.

Upon addition of polyether I to the culture medium no essential dependence of the accumulated recombinant cell biomass on the concentration of the additive was established. The total increase of cell biomass with this additive was $11 \%-19 \%$ when compared to control. Addition of polyether II caused the maximum biomass concentration increase in the culture medium (by 37\%) among all the PFCs (and their concentrations) studied. In terms of $\mathrm{His}_{6}-\mathrm{OPH}$-activity of the cells the optimum concentration of polyether I was $0.5 \%(v / v)$, and that of polyether II was $1 \%(v / v)$.

Analysis of the evaluated total enzymatic activity accumulated in the cells (Table 3 ) has shown that the maximum efficiency can be achieved for PFH and polyether concentration in the culture medium within the range of $0.5 \%-1 \%(v / v)$. Increasing the concentration of PFCs beyond $1 \%(v / v)$ was inefficient, because there was no further increase in biomass accumulation or the specific activity of the cells to show for the additional PFC that was spent.

These results differ from those that are published in other works [13,15], where the optimum concentration of PFD in the medium for cultivating E. coli cells was $5 \%$ or $50 \%(v / v)$. Thus, using PFH and polyethers for obtaining recombinant proteins from E. coli cells was more efficient as compared to PFD, because the maximum of the target active enzyme quantity was achieved at relatively low concentration of PFCs additive to the culture medium. 
Table 3. Total $\mathrm{His}_{6}-\mathrm{OPH}$ activity (U/L), accumulated in the E. coli SG13009[pREP4] cells in the presence of various PFCs in the culture medium *.

\begin{tabular}{ccccccc}
\hline \multirow{2}{*}{ PFCs } & \multicolumn{7}{c}{ Concentration $\mathbf{( \% \text { v/v) }}$} \\
\cline { 2 - 7 } & $\mathbf{0 . 3}$ & $\mathbf{0 . 5}$ & $\mathbf{1}$ & $\mathbf{2}$ & $\mathbf{3}$ & $\mathbf{5}$ \\
\hline Perfluorohexane & $389.4 \pm 19.2$ & $410.7 \pm 19.8$ & $384.8 \pm 18.9$ & $325.6 \pm 18.0$ & $335.0 \pm 16.2$ & $271.9 \pm 13.2$ \\
Perfluorodecalin & $334.4 \pm 16.1$ & $339.9 \pm 16.8$ & $341.7 \pm 16.8$ & $360.1 \pm 16.9$ & $337.0 \pm 16.5$ & $325.8 \pm 15.3$ \\
Polyether I & $373.9 \pm 18.3$ & $384.2 \pm 18.7$ & $396.7 \pm 19.6$ & $337.7 \pm 19.2$ & $371.6 \pm 18.2$ & $350.3 \pm 16.5$ \\
Polyether II & $361.7 \pm 18.0$ & $441.1 \pm 21.2$ & $463.5 \pm 22.3$ & $383.5 \pm 20.7$ & $380.0 \pm 18.6$ & $308.2 \pm 14.9$ \\
\hline
\end{tabular}

${ }^{*}$ Total $\mathrm{His}_{6}$-OPH-activity of cells cultivated in the absence of PFCs (control) was $325.6 \pm 15.3 \mathrm{U} / \mathrm{L}$.

It was established that the highest total $\mathrm{His}_{6}-\mathrm{OPH}$ activity per $1 \mathrm{~L}$ of culture medium was provided by the two substances, PFH and polyether II, which have the highest $\mathrm{O}_{2}$ solubility at $298 \mathrm{~K}$ among the PFCs studied (Table 1).

The evaluated total $\mathrm{His}_{6}$-OPH activity of the accumulated cells per $1 \mathrm{~L}$ of culture medium was higher by $11 \%$ in the presence of polyether II than that in the presence of PFH. However, the latter PFC, being a commercially available product with strictly standardized characteristics, appears to be the better choice for practical applications involving the biosynthesis of recombinant proteins. Taking this into consideration, we used PFH with a concentration of 0.5 vol. \% in our further experiments.

\subsection{Studying the Possibility of muLtiple re-Use of Gas Transport-Capable Substances in Biosynthesis of Intracellular Proteins}

When PFCs are used for cultivation of microorganisms with exoproducts, the fluoroorganic phase becomes separated from the culture medium upon the termination of the process and precipitation of the compound to the bottom of the reactor [12]. Since $\mathrm{His}_{6}-\mathrm{OPH}$ is an intracellular enzyme, re-use of gas transport-capable substances in the biosynthesis of this enzyme requires an essentially different approach.

In order to obtain the target enzyme, the $\mathrm{His}_{6}-\mathrm{OPH}$-containing biomass of E. coli SG13009[pREP4] cells that accumulated during cultivation in the presence of 0.5 vol. \% of PFH was disintegrated in the presence of phosphate buffer, and the resulting supernatant was used for protein isolation, in accordance to standard techniques [32]. The remaining precipitate of cell debris, being in fact a mixture of disintegrated cell biomass and PFH, was added to the TYE culture medium instead of the pure fluorocarbon and $1 / 4$ of yeast extract, which were used for the 1-st biotechnological round of biomass accumulation (Figure 2).

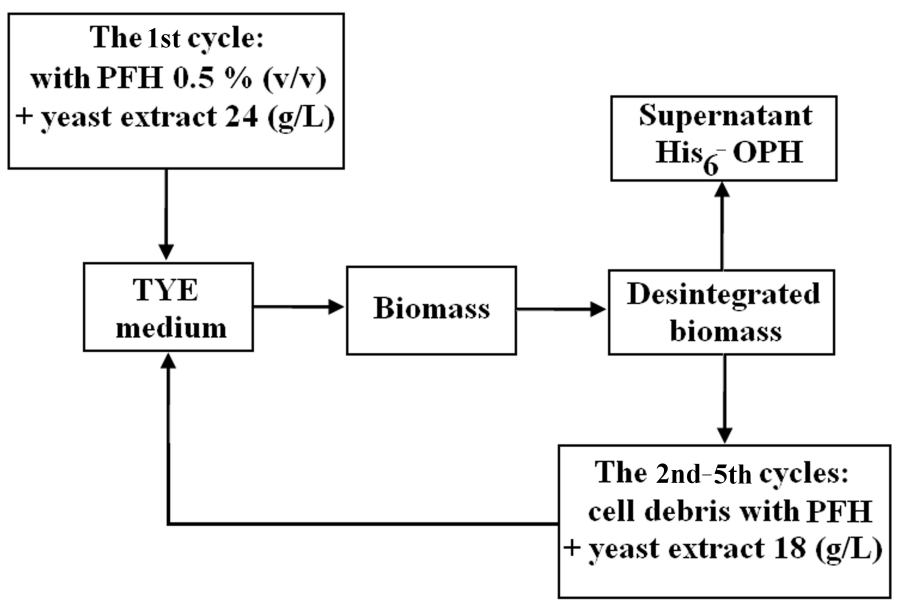

Figure 2. General scheme of the recycling process of perfluorohexane (PFH) present in the disintegrated biomass. 
The culture medium thus obtained was used for the accumulation of the next batch cultivation of $\mathrm{His}_{6}-\mathrm{OPH}$-containing cells (Figures 2 and 3). This procedure was repeated five times. For control, the E. coli SG13009[pREP4] cells were cultivated in TYE culture medium, where $1 / 4$ of the yeast extract was replaced with disintegrated biomass accumulated in the absence of PFH.

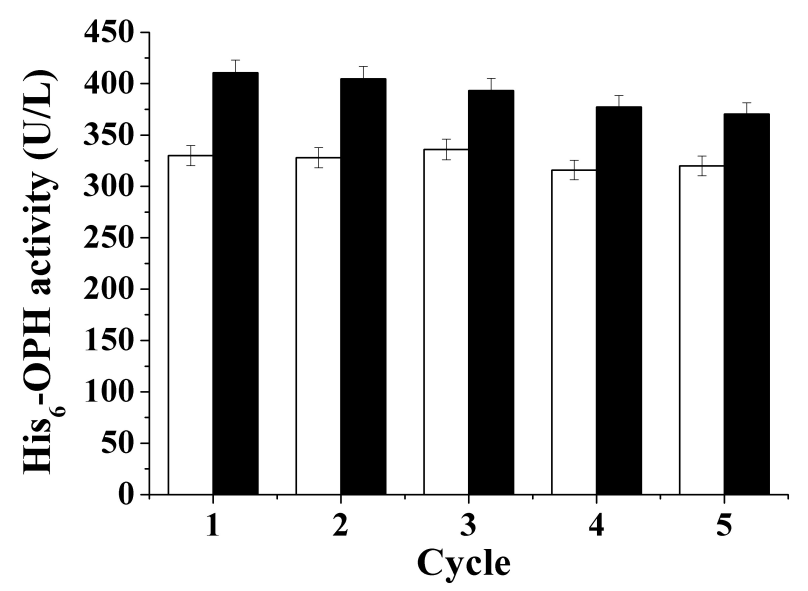

Figure 3. Accumulation of the total $\mathrm{His}_{6}-\mathrm{OPH}$ activity in the course of multiple batch re-use of $\mathrm{PFH}$ (white bars-control, black bars-cells cultivated in the medium containing $0.5 \%(v / v)$ of PFH).

The total level of enzyme activity accumulated in the second stage of $\mathrm{His}_{6}$-OPH biosynthesis, when "recycled" PFH was used instead of the "pure" one, was little lower than that obtained from the first stage. During the following three cycles of using the "recycled" PFH, the amount of accumulated biomass remained practically the same, whereas the level of $\mathrm{His}_{6}-\mathrm{OPH}$ activity slightly decreased. The latter was probably due to the gradual loss of PFH in the "recycling" process. This loss, though inevitable due to the high volatility of PFH, was however not significant, as can be concluded from the results of cultivation.

Electrophoretic analysis under non-denaturing (Figure 4a) and denaturing conditions (Figure $4 b$ ) was performed for $\mathrm{His}_{6}$-OPH protein isolated from the biomass of E. coli SG13009[pREP4] cells that accumulated during cultivating under standard conditions, as well in case of addition of $0.5 \mathrm{vol} . \%$ of $\mathrm{PFH}$, both the pure one and that "recycled" from the disintegrated biomass remaining from the previous stage. All of the samples produced similar bands near the $36 \mathrm{kDa}$ marker, which are routinely observed during analysis of purified $\mathrm{His}_{6}-\mathrm{OPH}$ via SDS electrophoresis following the standard technique [32].

There were received lines at the level of the protein marker, with a molecular weight of $36 \mathrm{kDa}$ in all of the samples under denaturing conditions, as standard obtained by analysis of purified $\mathrm{His}_{6}-\mathrm{OPH}$ by using SDS-PAGE in a known manner [32]. It was established that the addition of PFH to the medium for cell cultivation slightly increased the total amount of the $\mathrm{His}_{6}-\mathrm{OPH}$ in the cells, and the amount of soluble protein fraction (Figure 4), which explains the observed increase in $\mathrm{His}_{6}$-OPH activity in the cells cultured in the presence of PFH.

The PAGE analysis of the same proteins that were isolated from the biomass of E. coli SG13009[pREP4] cells under non-denaturing conditions showed that PFH addition in the medium leads to a noticeable decrease in the share of oligomerization forms of the enzyme (Figure 4a), which as a rule, have less enzymatic activity [33]. Thus, the addition of PFH to culture medium for E. coli SG13009[pREP4] cells increased the yield of soluble and active form of the enzyme $\mathrm{His}_{6}-\mathrm{OPH}$. 


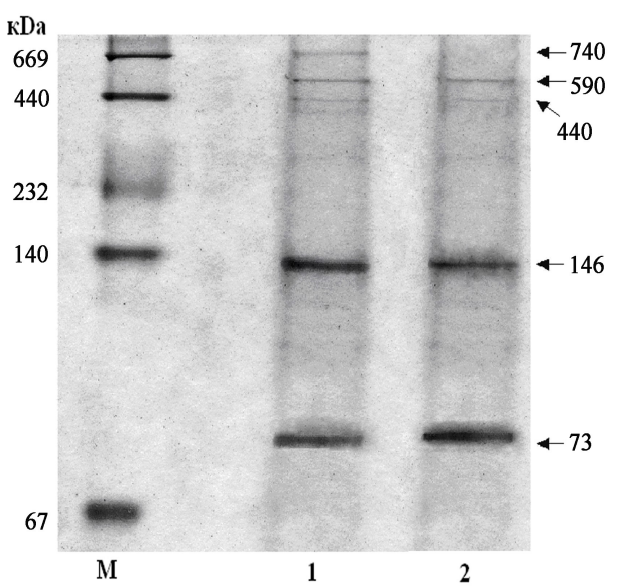

(a)

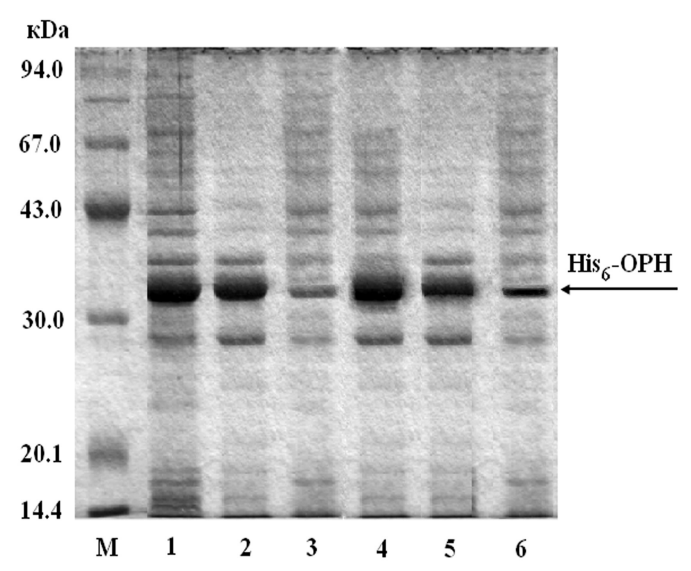

(b)

Figure 4. The electrophoregram conducted under non-denaturing (a) (1-without PFH addition, 2-with PFH addition) and denaturing (b) conditions (1-3 without PFH addition, 4-6 with PFH addition, the 1,4-total protein fractions; 2,5-insoluble protein fractions, 3,6-soluble fraction), reflecting the impact of the presence of $\mathrm{PFH}$ in the culture medium on the biosynthesis of OPH. $\mathrm{M}$-markers of molecular weight.

\section{Discussion}

We performed an analysis of published data on the known techniques for cultivating E. coli cells for producing $\mathrm{His}_{6}-\mathrm{OPH}$. Based on these data, the total $\mathrm{His}_{6}-\mathrm{OPH}$ activity per liter of culture medium was evaluated for each case summarized in Table 4.

Table 4. Basic characteristics of various techniques for producing $\mathrm{His}_{6}-\mathrm{OPH}$.

\begin{tabular}{ccccc}
\hline E. coli Strain & $\begin{array}{c}\text { Yield of Biomass } \\
\text { (CDW/L) }\end{array}$ & $\begin{array}{c}\mathbf{A}_{\max }{ }^{*} \text { in the Cells } \\
\text { (U/g) }\end{array}$ & $\begin{array}{c}\text { Process } \\
\text { Productivity } \\
\text { (U/L/h) }\end{array}$ & $\begin{array}{c}\text { Total His } 6 \text {-OPH } \\
\text { Activity (U/L) }\end{array}$ \\
\hline \multirow{2}{*}{ DH5a [33] } & 2.8 & 130 & 17.3 & 364.0 \\
& 5.8 & 44 & 12.2 & 255.2 \\
\hline W3110 [34] & 2.7 & 38 & 5.1 & 102.6 \\
\hline SG13009[pREP4] [34] & 4.3 & 34 & 6.1 & 146.2 \\
\hline \multirow{2}{*}{ SG13009[pREP4] } & a 3.7 & 88 & 13.6 & 325.6 \\
(this work) & $\mathrm{b} 5.1$ & 91.5 & 19.3 & 463.5 \\
& $\mathrm{c} 4.4$ & 93.3 & 17.1 & 410.7 \\
\hline
\end{tabular}

${ }^{*} \mathrm{~A}_{\max }$ is the maximum His $_{6}-\mathrm{OPH}$ activity of the cells obtained upon cultivation, ${ }^{a}$ Conditions reported previously [33]; ${ }^{\mathrm{b}}$ Addition of $1 \%(v / v)$ of polyether $\mathrm{II}^{\circ}{ }^{\mathrm{c}}$ Addition of $0.5 \%(v / v)$ of $\mathrm{PFH}$.

Comparison of the results of various studies has shown that addition of PFCs to the culture medium allows for accumulating the maximum total $\mathrm{His}_{6}-\mathrm{OPH}$ activity per $1 \mathrm{~L}$ of medium. Note that cultivating E. coli cells for producing $\mathrm{His}_{6}-\mathrm{OPH}$ under conditions used previously resulted [34] in some cases to the accumulation of greater biomass or higher $\mathrm{His}_{6}-\mathrm{OPH}$ activity of the cells as compared to the data obtained in present study. However, only the addition of PFH and polyether II allowed for increasing the specific rate of cell growth, $\mathrm{His}_{6}-\mathrm{OPH}$ activity of the cells and the concentration of accumulated biomass in the medium. Thus, the combination of these effects resulted in the maximum increase of the total $\mathrm{His}_{6}$-OPH activity per $1 \mathrm{~L}$ of the culture medium, so the overall efficiency of cell cultivation process improved.

As compared to the productivity of the various processes of $\mathrm{His}_{6}-\mathrm{OPH}$, accumulation has shown that the addition of $1 \%(v / v)$ of polyether II ensures maximizing of this parameter. However the 
productivity of cells in present of polyether II was slightly higher that the same parameter obtained by adding PFH to the culture medium (Table 4).

Additionally, taking in to account the high price of polyether II as reagent for biotechnology processes, we certainly should recommend the application of PFH for the use in production of His $_{6}-\mathrm{OPH}$ in E. coli SG13009[pREP4] cell.

\section{Conclusions}

Thus, addition of gas transport-capable substances to the medium for culturing recombinant cells in order to produce intracellular $\mathrm{His}_{6}-\mathrm{OPH}$ proved prospective. The best choice among the studied PFCs for producing $\mathrm{His}_{6}-\mathrm{OPH}$ was using PFH with concentration of $0.5 \%(v / v)$ as the culture medium additive, which allowed for increasing the total $\mathrm{His}_{6}-\mathrm{OPH}$ activity by $26 \%$. It was also found that a further increase of the amount of the additive leads predominantly to a cell biomass increase, but does not cause an increase in the intracellular $\mathrm{His}_{6}-\mathrm{OPH}$ activity.

It was found that PFH present in the disintegrated biomass precipitate accumulated during each cycle of cell cultivation can be re-used in the following stages at least five times without the need for adding a fresh portion of the substance.

The approach demonstrated in this paper for increasing the output of the enzyme can be of use to other researchers developing biotechnological processes for producing various recombinant proteins.

\section{Patents}

This work is significant, because it allows for obtaining more enzyme amounts useful to realise biotechnological processes described in a number of patents based on the use of the $\mathrm{His}_{6}$-OPH for for detoxification and neutralization of organophosphorus compounds in soil and flow systems (RU Patent 2615176, 2017; RU Patent 2017101197, 2017; RU Patent 2575627, 2016; RU Patent 2525658, 2014; RU Patent 2451077, 2012; RU Patent 2408724, 2011; RU Patent 2315103, 2008), neutralization of mycotoxins (RU Patent 2016148169, 2016), production of self-detoxifying material for personal protection against the action of organophosphorus neurotoxins (RU Patent 2330717, 2008).

Acknowledgments: The present work was funded by the Russian Science Foundation (Grant No. 16-14-00061).

Author Contributions: All authors conceived and designed the experiments; O.S., N.S. and T.M. performed the biotechnological experiments; A.T., S.S. and V.G. performed the experiments of production and characterization perfluorocarbon compounds; O.S., S.T. and E.E. analyzed the data and wrote the paper. All authors approved the final version of the manuscript.

Conflicts of Interest: The authors declare no conflict of interest.

\section{References}

1. Rosano, G.L.; Ceccarelli, E.A. Recombinant protein expression in Escherichia coli: Advances and challenges. Front. Microbiol. 2014, 5, 172. [CrossRef] [PubMed]

2. Jia, B.; Jeon, C.O. High-throughput recombinant protein expression in Escherichia coli: Current status and future perspectives. Open Biol. 2016, 6, 160196. [CrossRef] [PubMed]

3. Fakruddin, M.; Mohammad Mazumdar, R.; Bin Mannan, K.S.; Chowdhury, A.; Hossain, M.N. Critical factors affecting the success of cloning, expression, and mass production of enzymes by recombinant $E$. coli. ISRN Biotechnol. 2013, 2013, 590587. [CrossRef] [PubMed]

4. Spadiut, O.; Capone, S.; Krainer, F.; Glieder, A.; Herwig, C. Microbials for the production of monoclonal antibodies and antibody fragments. Trends Biotechnol. 2014, 32, 54-60. [CrossRef] [PubMed]

5. Tripathi, N.K.; Shrivastva, A.; Biswal, K.C.; Lakshmana Rao, P.V. Optimization of culture medium for production of recombinant dengue protein in Escherichia coli. Ind. Biotechnol. 2009, 5, 179-183. [CrossRef]

6. Kamionka, M. Engineering of therapeutic proteins production in Escherichia coli. Curr. Pharm. Biotechnol. 2011, 12, 268-274. [CrossRef] [PubMed] 
7. Baeshen, M.N.; Al-Hejin, A.M.; Bora, R.S.; Ahmed, M.M.; Ramadan, H.A.; Saini, K.S.; Baeshen, N.A.; Redwan, E.M. Production of biopharmaceuticals in E. coli: Current scenario and future perspectives. J. Microbiol. Biotechnol. 2015, 25, 953-962. [CrossRef] [PubMed]

8. Garcia-Ochoa, F.; Gomez, E. Bioreactor scale-up and oxygen transfer rate in microbial processes: An overview. Biotechnol. Adv. 2009, 27, 153-176. [CrossRef] [PubMed]

9. Ibrahim, D.; Weloosamy, H.; Lim, S.-H. Effect of agitation speed on the morphology of Aspergillus niger HFD5A-1 hyphae and its pectinase production in submerged fermentation. World J. Biol. Chem. 2015, 6, 265-271. [CrossRef] [PubMed]

10. Lowe, K.C. Perfluorochemical respiratory gas carriers: Benefits to cell culture systems. J. Fluorine Chem. 2002, 118, 19-26. [CrossRef]

11. Pilarek, M.; Szewczyk, K.W. Effects of perfluorinated oxygen carrier application in yeast, fungi and plant cell suspension cultures. Biochem. Eng. J. 2008, 41, 38-42. [CrossRef]

12. Vieira, E.S.; de Oliveira Fontes, K.T.; Pereira, M.M.; Alexandre, H.V.; da Silva, D.P.; Soares, C.M.F.; Lima, A.S. New strategy to apply perfluorodecalin as an oxygen carrier in lipase production: Minimisation and reuse. Bioprocess. Biosyst. Eng. 2015, 38, 721-728. [CrossRef] [PubMed]

13. Martinson, E.A.; Birjukov, V.V.; Bakulin, V.M.; Kruchkov, A.V.; Sincov, K.N. Influence of perfluorodecalin on growth of Escherichia coli of M-17 at deep cultivation. Fundam. Res. 2014, 5, 71-74.

14. Pilarek, M. Liquid perfluorochemicals as flexible and efficient gas carrier applied in bioprocess engineering an updated overview and future prospect. Chem. Process. Eng. 2014, 35, 463-487. [CrossRef]

15. Pilarek, M.; Brand, E.; Hillig, F.; Krause, M.; Neubauer, P. Enhanced plasmid production in miniaturized high-cell-density cultures of Escherichia coli supported with perfluorinated oxygen carrier. Bioprocess. Biosyst. Eng. 2013, 36, 1079-1086. [CrossRef] [PubMed]

16. Lowe, K.C.; Davey, M.R.; Power, J.B. Perfluorochemicals: Their applications and benefits to cell culture. Trends Biotechnol. 1998, 16, 272-277. [CrossRef]

17. Pilarek, M.; Glazyrina, J.; Neubauer, P. Enhanced growth and recombinant protein production of Escherichia coli by a perfluorinated oxygen carrier in miniaturized fed-batch cultures. Microb. Cell Fact. 2011, 10, 50. [CrossRef] [PubMed]

18. Grunzel, P.; Pilarek, M.; Steinbrück, D.; Neubauer, A.; Brand, E.; Kumke, M.U.; Neubauer, P.; Krause, M. Mini-scale cultivation method enables expeditious plasmid production in Escherichia coli. Biotechnol. J. 2014, 9, 128-136. [CrossRef] [PubMed]

19. Bakulin, M.K.; Grudtsyna, A.S.; Pletneva, A.Y.; Kucherenko, A.S.; Lyapustin, A.V.; Malakhov, I.G. Effect of perfluorodecalin, carbogal, and perfluoromethyldecalin on growth and ice-forming activity of bacteria. Microbiology 2006, 75, 312-316. [CrossRef]

20. Su, L.; Shen, Y.; Gao, T.; Luo, J.; Wang, M. Improvement of AD biosynthesis response to enhanced oxygen transfer by oxygen vectors in Mycobacterium neoaurum TCCC 11979. Appl. Biochem. Biotechnol. 2017, 182, 1564-1574. [CrossRef] [PubMed]

21. Lyagin, I.V.; Andrianova, M.S.; Efremenko, E.N. Extensive hydrolysis of phosphonates as unexpected behaviour of the known $\mathrm{His}_{6}$-organophosphorus hydrolase. Appl. Microbiol. Biotechnol. 2016, 100, 5829-5838. [CrossRef] [PubMed]

22. Efremenko, E.N.; Lyagin, I.V.; Klyachko, N.L.; Bronich, T.; Zavyalova, N.V.; Jiang, Y.; Kabanov, A.V. A simple and highly effective catalytic nanozyme scavenger for organophosphorus neurotoxins. J. Control Release 2017, 247, 175-181. [CrossRef] [PubMed]

23. Sirotkina, M.; Efremenko, E.N. Rhodococcus lactonase with organophosphate hydrolase (oph) activity and his-tagged oph with lactonase activity: Evolutionary proximity of the enzymes and new possibilities in their application. Appl. Microbiol. Biotechnol. 2014, 98, 2647-2656. [CrossRef] [PubMed]

24. Maslova, O.V.; Senko, O.V.; Stepanov, N.A.; Aslanli, A.G.; Efremenko, E.N. His 6 -OPH and its stabilized forms combating quorum sensing molecules of gram-negative bacteria in combination with antibiotics. Jundishapur J. Nat. Pharm. Prod. 2017, in press. [CrossRef]

25. Efremenko, E.N.; Votchitseva, Y.A.; Aliev, T.K.; Varfolomeev, S.D. Recombinant Plasmid DNA pTES-HIS-OPH and Producer of Oligohistidine-Containing Organophosphate Hydrolase. RU Patent 2255975 C 1, 10 July 2005.

26. Lyagin, I.V.; Efremenko, E.N. Biomolecular engineering of biocatalysts hydrolyzing neurotoxic organophosphates. Biochimie 2018, 144, 115-121. [CrossRef] [PubMed] 
27. Freire, M.G.; Dias, A.M.A.; Coelho, M.A.Z.; Coutinho, J.A.P.; Marrucho, I.M. Aging mechanisms of perfluorocarbon emulsions using image analysis. J. Colloid Interface Sci. 2005, 286, 224-232. [CrossRef] [PubMed]

28. Efremenko, E.; Votchitseva, Y.; Plieva, F.; Galaev, I.; Mattiasson, B. Purification of His 6 -organophosphate hydrolase using monolithic supermacroporous polyacrylamide cryogels developed for immobilized metal affinity chromatography. Appl. Microbiol. Biotechnol. 2006, 70, 558-563. [CrossRef] [PubMed]

29. Berney, M.; Weilenmann, H.-U.; Julian Ihssen, J.; Bassin, C.; Egli, T. Specific growth rate determines the sensitivity of Escherichia coli to thermal, UVA, and solar disinfection. Appl. Environ. Microbiol. 2006, 72, 2586-2593. [CrossRef] [PubMed]

30. Ntwampe, S.K.O.; Williams, C.C.; Sheldon, M.S. Influence of perfluorocarbons on Phanerochaete. chrysosporium biomass development, substrate consumption and enzyme production. Chem. Biochem. Eng. Q. 2010, 24, 187-194.

31. Elibola, M.; Mavitunab, F. A remedy to oxygen limitation problem in antibiotic production: Addition of perfluorocarbon. Biochem. Eng. J. 1999, 3, 1-7. [CrossRef]

32. Efremenko, E.; Lyagin, I.; Votchitseva, Y.; Sirotkina, M.; Varfolomeyev, S. Polyhistidine-containing organophosphorus hydrolase with outstanding properties. Biocatal. Biotransform. 2007, 25, 103-108. [CrossRef]

33. Efremenko, E.N.; Votchitseva, Y.A.; Aliev, T.K.; Varfolomeyev, S.D. Expression of recombinant organophosphorus hydrolase in active form. In Biocatalytic Technology and Nanotechnology; Zaikov, G.E., Ed.; Nova Science Publishers, Inc.: New York, NY, USA, 2004; pp. 65-71. ISBN 1-59454-117-5.

34. Efremenko, E.N.; Lyagin, I.V.; Votchitseva, Y.V.; Gudkov, D.A.; Peregudov, A.A.; Aliev, T.K.; Varfolomeev, S.D. The influence of length and localization of polyhistidine tag in the molecule of organophosphorus hydrolase on the biosynthesis and behavior of fusion protein. In Biotechnology: State of the Art and Prospects for Development; Zaikov, G.E., Ed.; Nova Science Publishers, Inc.: New York, NY, USA, 2008; pp. 87-101, ISBN 978-1-60456-015-2. 